\title{
FAMILIARESOU DESCONHECIDOS? A relação entre os protagonistas do estupro no fluxo do Sistema de Justiça Criminal*
}

\section{Joana Domingues Vargas}

\section{Introdução}

Neste artigo, pretendo mostrar as vantagens, para o estudo dos crimes e de seus protagonistas, de se deslocar a análise das decisões tomadas em cada subsistema do Sistema de Justiça Criminal polícia, Ministério Público e varas criminais - para a investigação do fluxo de procedimentos e da clientela que atravessa essas diferentes organizações. ${ }^{1}$ Para tanto, focalizarei 0 crime de estupro, tomando por objeto uma das características dos envolvidos: 0 relacionamento existente entre eles. O objetivo é investigar em que medida a natureza e o grau do relacionamento entre agressor e vítima determinam, neste tipo de crime, as decisões do Sistema de Justiça Criminal, e se há diferenças no tratamento dado a agressores conhecidos e desconhecidos da vítima pelos três subsistemas, nas várias fases do fluxo.

\section{E statísticas de crimes sex uais}

Boa parte da literatura produzida sobre a violência contra a mulher, a criança e 0 adolescente no Brasil tem privilegiado, como fonte de pesquisa, documentos elaborados no Sistema de Justiça Criminal. ${ }^{2}$ Estatísticas produzidas a partir de boletins de ocorrências, da análise de processos e de prontuários de medicina legal vêm derrubando alguns mitos até então predominantes no universo simbólico em geral. Em relação ao crime de estupro, um desses mitos consistia em acreditar que os agressores são desconhecidos da vítima (Souza et al., 1993).

Os primeiros dados mais consistentes trazidos a público (Azevedo e Azevedo Guerra, 1988; Cohen e Matsuda, 1990, apud Cohen, 1993) ${ }^{3}$ relativos à violência sexual em geral (estupro, tentativa de estupro, atentado violento ao pudor) buscaram revelar o grau de parentesco existente entre as

* Uma parte dos dados da pesquisa que resultou neste texto foi utilizada na elaboração de minha dissertação de mestrado, realizada sob a orientação da professora Alba Zaluar. A outra parte encontra-se em fase de organização e análise e está sendo desenvolvida para 0 doutorado, sob a orientação do professor Edmundo Campos Coelho. Obtive financiamento da CAPES, da Fundação João Pinheiro e, atualmente, do CNPq. Também recebi bolsa da Anpocs e do FAEP/Unicamp. Agradeço a colaboração de Selma Christien Rodrigues (na fase da delegacia), Beatriz Caiubi Labate (na fase do Fórum), Gustavo Aprile Rossi e Fábio Fonseca Duarte (na codificação dos dados e observação estatística), e as leituras de Patrícia Campos de Sousa e de Lea Carvalho Rodrigues. 
partes. Entretanto, os resultados apresentavam tal disparidade que era impossível atribuí-la apenas às diferentes lógicas empregadas pelas organizações que os produziram; 4 antes se devia às metodologias diversas utilizadas pelos pesquisadores. Azevedo e Azevedo Guerra (1988), reproduzindo as designações contidas nos boletins de ocorrências (BOs), que não contemplam nenhum registro sobre 0 relacionamento entre agressor e vítima, encontraram apenas 0,05\% de casos de incesto. Já Cohen e Matsuda (1990, apud Cohen, 1993), a partir de entrevistas realizadas com vítimas atendidas no Instituto Médico Legal (IML), identificaram 21\% de casos incestuosos. ${ }^{5}$ Uma análise e comparação desses dados, realizadas posteriormente por Saffiotti (1994), apontam, além desta, uma outra razão para explicar essa diferença nas porcentagens: a criação de delegacias especializadas no atendimento a esses crimes - as Delegacias de Defesa da Mulher (DDMs) - , provável responsável pelo aumento das queixas no período decorrido entre uma e outra investigação. Neste mesmo estudo, após sanar a ausência de informação com respeito ao relacionamento entre os envolvidos nos BOs das 1a e 8 a DDMs de São Paulo, a autora encontrou, para a primeira delegacia, 23,2\% de estupros incestuosos em 1991 e 36\% em 1992; já para a segunda, registrou 25\% de estupros incestuosos em 1992. ${ }^{6}$ Em estudo mais recente, Pimentel et al. (1998), analisando dados de estupros coletados em 50 processos referentes às cinco regiões brasileiras, concluíram que $70 \%$ dos envolvidos se conheciam e, destes, 18\% mantinham relacionamentos incestuosos. ${ }^{7}$

Três considerações a respeito desses dados. A primeira, mais óbvia, é que eles se referem às denúncias absorvidas pelo Sistema de Justiça Criminal e não às manifestações efetivas desses crimes na sociedade. Conforme observaram todos os que estudaram esta modalidade de crime, há uma diferença entre a realidade e o que vem a público difícil de ser mensurada. A segunda consideração é sobre a necessidade de se observar as operações de classificação e seleção empreendidas pelos pesquisadores, que, como vimos, podem gerar diferentes resultados. A terceira, que será particularmente explorada neste trabalho, é que os da- dos produzidos no sistema são o reflexo das operações que este executa, dentre elas a de realizar a subsunção da ocorrência à norma penal e a de classificá-la tendo por referência 0 conhecimento da maneira típica como tais crimes são cometidos (Sudnow, 1965). Esta orientação parte do pressuposto de que os procedimentos e decisões tomados no Sistema de Justiça Criminal são ancorados sobretudo em processos de rotulação e estereotipagem (Becker, 1963; Goffman, 1982), bem como em tipificações acordadas entre todos os envolvidos (Cicourel, 1968; Paixão, 1982). Nesse sentido, são os processos de elaboração dos dados e, sobretudo, as atividades rotineiras das quais eles resultam que me interessa abordar. Ao verificar como os dados foram construídos, somos informados sobre como crimes e criminosos são produzidos (Cicourel, 1968).

Crimes sexuais e o fluxo do Sistema de Justiça Criminal

A estas premissas soma-se a perspectiva de que, como já foi dito, a investigação dos crimes e de seus protagonistas deve se dar a partir da análise do seu fluxo ao longo das diferentes fases de funcionamento do Sistema de Justiça Criminal - queixa, inquérito, denúncia e sentença. Elas me permitem indagar se 0 relacionamento entre agressor e vítima condiciona uma menor ou maior penalização do crime de estupro, e se esta é uniforme ao longo de todas as fases do fluxo.

Para fazer semelhante investigação, é necessário considerar que, de acordo com os códigos e as atividades práticas dos operadores do sistema, para cada tipo de delito corresponde uma maneira singular de tratamento dos casos. Em crimes de estupro, a primeira singularidade refere-se à sua tipificação no artigo 213 do Código Penal Brasileiro como "constranger mulher a conjunção carnal mediante violência e grave ameaça" - com pena de três a oito anos, aumentada pela Lei dos Crimes Hediondos para de seis a dez anos - , delimitando, portanto, a vítima-mulher ou a vítima-menina como o sujeito passivo desta ação. Já as relações incestuosas cometidas por pai, padrasto ou responsável legal não são tipificadas como crime enquanto tal no Código Penal, no qual o incesto figura apenas como circunstância agravante do crime de es- 
tupro se a vítima for menor de 14 anos, o que configura também a violência presumida. ${ }^{8}$ Desse modo, interessa saber em que medida as disposições definidas em lei condicionam e explicam o comportamento do fluxo do ponto de vista do relacionamento entre as partes em todas as suas fases.

Uma outra singularidade do crime de estupro é o caráter privado da ação penal, ou seja, a decisão de acionar o sistema é da vítima ou de seu representante legal, exceção feita aos casos em que 0 agressor é 0 próprio pai ou 0 responsável legal da vítima menor de 14 anos e àqueles que resultam em lesão grave ou morte, quando cabe ao promotor a incumbência de promover a ação, independente da manifestação dos queixosos. Isto confere aos queixosos deste tipo de delito um papel crucial na definição de quais ocorrências e autores darão entrada no sistema. Desta perspectiva, parece essencial analisar como e em que medida a natureza da ação penal determina o comportamento da variável em questão na fase inicial do fluxo.

Uma terceira particularidade do crime de estupro, igualmente importante, é o fato de se contar com poucas versões originais sobre 0 acontecimento (em geral, apenas a versão da vítima e, com menor freqüência, as versões dela e do agressor) e de se apresentarem inúmeras dificuldades para a comprovação de sua materialidade. A carência de provas e de testemunhos torna ainda mais patente 0 uso, pelos envolvidos e pelos operadores do sistema, de concepções estigmatizantes permanentemente negociadas entre eles (Cicourel, 1968), relacionando a ocorrência à maneira típica como esses crimes ocorrem (Sudnow, 1965). A carência de provas e testemunhos confere à palavra da vítima o caráter de prova, reconhecida por lei. Pode-se imaginar que, decorrente deste fato, haja uma preocupação constante dos operadores com a verossimilhança do depoimento dado pela vítima e com a sua contaminação pelo caráter relacional. Nesse sentido, interessa saber quais são as estratégias utilizadas pelos agentes do sistema para construir as evidências do crime. Em que medida elas são informadas pelo fato de as partes se conhecerem ou não?

Encerro este conjunto de indagações com algumas proposições que tentarei sustentar ao longo deste ensaio. Primeiro, que as disposições defi- nidas nos códigos apresentam-se como uma das instruções usadas pelos operadores do sistema para orientá-los no seu trabalho prático e, nesse sentido, desempenham um papel importante na definição do que deve ser considerado crime e do perfil dos envolvidos. No estudo em questão, por exemplo, suponho que a ação penal independente da vontade dos queixosos quando a vítima é menor de 14 anos e 0 pai, padrasto ou responsável legal é 0 agressor deva refletir-se na concentração de relações incestuosas contra menores de 14 anos, sobretudo a partir da fase de inquérito.

Mas, estas disposições nada dizem sobre como estabelecer a correspondência entre 0 que está estatuído e os casos em questão. Para aplicar a lei, os operadores devem lançar mão de um outro tipo de conhecimento, qual seja, de instruções informadas pelo modo como esses crimes são normalmente cometidos, e suas características típicas, dos quais os operadores tomam conhecimento por meio de sua socialização e experiência na profissão (Sudnow, 1965). ${ }^{9}$ São essas instruções que permitem caracterizar, reconhecer, classificar e diferenciar os estupros cometidos por desconhecidos e conhecidos e o perfil dos envolvidos.

Sobre este aspecto, é de conhecimento dos operadores (e não só deles) que a descrição mais comum dos estupros cometidos por desconhecidos relata uma abordagem feita na rua, muitas vezes com o uso de armas, por "indivíduos jovens, de estrato social mais baixo, que têm desvio de comportamento sexual, têm problema de timidez ou são impotentes". ${ }^{10}$ E 0 que eu procurarei argumentar neste artigo é que autores desconhecidos se encaixam melhor no estereótipo do estuprador, facilitando as decisões rotineiras dos operadores e a denúncia dos queixosos.

Já os agressores conhecidos são identificados principalmente como pais de meia idade, que agem repetidamente em casa quando a mãe não está presente. A queixa que envolve familiares também adquire uma caracterização que lhe é própria: "muitas vezes a mãe tenta retirar a queixa, por medo, por não querer que 0 marido perca 0 emprego, então diz que mentiu [...] são casos e mais casos em que é a palavra da criança contra a família inteira". ${ }^{11}$ Irei sustentar que, ainda que o grau de relacionamento entre as par- 
tes seja fundamental para definir as estratégias dos operadores do Sistema de Justiça Criminal, já que se pode constituir em circunstância agravante do estupro, tal relação, por sua vez, acaba dificultando as decisões, na medida em que congrega conflitos pessoais, de conteúdo emocional.

Quanto às estratégias de construção de evidências, partirei do pressuposto de que as situações em que inexiste relação entre as partes permitem mais facilmente a elaboração de evidências para determinar a culpa. Isto ocorre, em parte, por configurarem a necessidade de investigação. É a partir dos métodos empregados para realizar a investigação (campana, interrogatório para se obter a confissão, reconhecimento do autor, inquirição da vítima etc.) e da confrontação de seus resultados com os casos característicos definidores desses crimes que as evidências vão sendo construídas. Já nos casos de envolvidos conhecidos, vítima e acusado são colocados em suspeição: são reconstituídos os elementos típicos que conferem sentido ao caso, avaliada a hipótese de uma possível armação, desenhados os perfis morais dos envolvidos, sobretudo o da vítima, e ponderadas as motivações. Quando se trata de acusações envolvendo crianças, a verossimilhança de sua narrativa é reconhecida mediante a eleição de certos indícios, tais como o seu conhecimento precoce de determinadas ocorrências do ato sexual, e são avaliadas as conseqüências sociais do ato e de sua denúncia.

Nas próximas seções procurarei mostrar, com a apresentação e contextualização dos dados provenientes de documentação produzida pelo Sistema de Justiça Criminal e por mim organizados, 0 lugar conferido pela vítima (ou seu representante legal) e pelos operadores do sistema, ao longo de todo o fluxo, aos agressores desconhecidos e àqueles conhecidos da vítima. Buscarei argumentar que, no crime de estupro, o relacionamento entre as partes envolvidas é um fator importante na tomada de decisões. Mas, antes, é necessária uma descrição da representação do fluxo adotada:

\section{Fluxo do Sistema de Justiça Criminal}

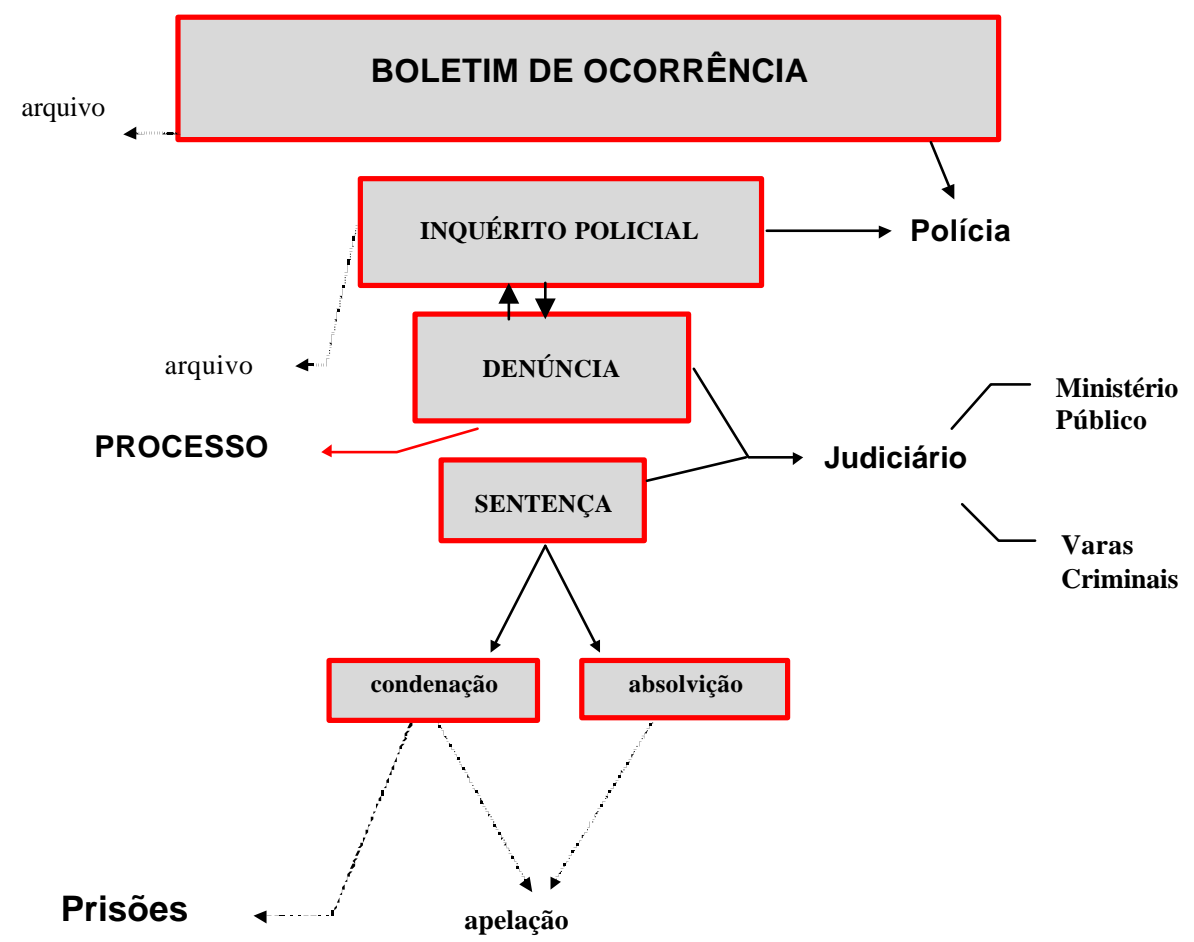

Tribunais de

$2^{a}$ Instância 
O fluxo do Sistema de Justiça Criminal constitui-se em torno do segmento Boletim de Ocorrência (BO)-Inquérito-D enúncia-Sentença. $\mathrm{O}$ BO, registro da queixa feita pela vítima ou seu representante legal, e o Inquérito Policial são produzidos pela polícia. Queixas de crimes sexuais, desde meados da década de 80, passaram a ser da competência de delegacias especializadas - as delegacias de atendimento a mulheres - em substituição às antigas delegacias de costumes. ${ }^{12} \mathrm{~A}$ Denúncia, em geral, é de responsabilidade do Ministério Público. ${ }^{13}$ Com ela encerra-se a fase que antecede 0 Processo. Este desenrola-se nas Varas Criminais, através das atuações da Defesa e da Acusação, dirigidas por um juiz que profere a Sentença, de condenação ou de absolvição. ${ }^{14} \mathrm{Em}$ ambos os casos cabe a apelação do promotor, do querelante ou da Defesa. Se aceita, os autos são julgados por um Tribunal de Segunda Instância. Por seu turno, os conflitos e os envolvidos não canalizados em algum desses procedimentos acabam tendo seus registros arquivados.

Uma das questões sobre o fluxo do Sistema de Justiça Criminal a ser investigada, tendo por foco o formato que ele assume, refere-se ao seu grau de integração e/ ou disjunção. ${ }^{15}$ Nesse sentido, será averiguado, a partir do comportamento dos dados referentes ao relacionamento entre agressor e vítima e ao grau deste relacionamento, se há coesão entre as decisões tomadas nas diferentes fases do fluxo ou se há também um certo antagonismo.

$\mathrm{Na}$ próxima seção faço uma breve descrição da pesquisa que deu origem aos dados apresentados neste artigo.

\section{A construção da pesquisa}

\section{A pesquisa}

A pesquisa a que este artigo se refere foi realizada ao longo dos anos de 1993 e 1994. Seu objeto é a administração da Justiça Criminal para crimes sexuais e o recorte estabelecido é a transformação do acontecimento em fato jurídico, que se inicia no momento em que o cidadão faz a queixa e culmina com a sentença de condenação. Para efeito de recorte empírico foi escolhida a cidade de
Campinas (SP), apostando-se na definição de um quadro que pudesse ser generalizado ao menos para as cidades de grande e médio porte da Região Sudeste. ${ }^{16}$

Quanto ao aspecto metodológico, foram utilizados basicamente dois tipos de abordagem: a antropológica, com 0 emprego das técnicas de observação participante e a realização de entrevistas, e 0 método quantitativo. Considerando o objetivo do presente artigo, darei, a seguir, maiores detalhes sobre 0 uso da abordagem quantitativa.

Insatisfeita com as estatísticas oficiais que me foram apresentadas durante 0 trabalho de campo na Delegacia de Defesa da Mulher (DDM) de Campinas, empenhei-me em ter acesso ao seu arquivo de registros de boletins de ocorrência e de livros de inquérito. ${ }^{17}$ Com base nesse arquivo, dei início à montagem de um banco de dados que, além das informações coletadas nos registros de ocorrências (BOs) e registros de inquéritos arquivados na DDM, foi acrescido, posteriormente, daquelas levantadas em fichas de cartórios do Fórum de Campinas. A partir daí foi iniciado o mapeamento quantitativo dos dados, mediante 0 cruzamento das variáveis selecionadas.

0 universo recortado foi o dos quatro crimes sexuais de maior incidência nos boletins de ocorrência da DDM: estupro, tentativa de estupro, atentado violento ao pudor e sedução. 0 período abordado é de cinco anos, entre 1988, data de criação desta delegacia, e 1992, ano anterior ao início da pesquisa. Dada a natureza do objeto um processamento de informações em forma de funil -, não foram utilizadas amostras, mas 0 conjunto de informações referentes a esses crimes coletadas em todos os boletins, registros de inquérito e fichas de processos. Ao todo foram analisados 911 BOs. A partir das informações ali obtidas verificou-se seus desdobramentos nos outros documentos.

Todas essas informações foram codificadas e organizadas em alguns itens temáticos. As variáveis que por ora nos interessam - 0 relacionamento entre agressor e vítima e o grau deste relacionamento - referem-se à caracterização destes crimes. Elas serão apresentadas e analisadas, na fase do Boletim de Ocorrência, para os 
quatro crimes selecionados, de forma a permitir uma comparação entre eles, e, posteriormente, apenas para o crime de estupro, dada a exigüidade de espaço. Tratando-se do cruzamento de três variáveis (relação por crime por fase do flux 0), sua representação será feita no formato de gráfico de barra. $^{18}$

Neste trabalho com os dados, pareceu-me imprescindível medir a ausência de informação e identificar a sua causa. Esta preocupação metodológica mostrou-se importante porque ajudou a dimensionar o dado conhecido, tornando as interpretações sobre ele mais acuradas. Ao longo do fluxo, a ausência de informação incorpora diferentes configurações devido ao formato de funil que 0 sistema assume. Na fase do BO, ela significa ausência da informação no formulário; ${ }^{19}$ na fase do inquérito, "inquérito não instaurado"; nas fases de denúncia e de sentença (considerando que, à medida que se avança no fluxo, as informações não acessadas vão sendo descartadas), ela significa "desfecho desconhecido".

Características e problemas dos dados sobre 0 relacionamento entre agressor e vítima

As variáveis referentes à relação entre indiciado e vítima e ao grau desta relação tiveram de ser construídas, uma vez que não há uma classificação prévia neste sentido nos registros elaborados pela polícia $^{20} \mathrm{Na}$ maioria das vezes, foi partindo da leitura de cada BO, principalmente do exame do histórico que expõe sinteticamente os fatos narrados por ocasião da queixa, mas também da comparação das informações contidas nos tópicos referentes aos nomes do agressor e do pai da vítima, que vestígios de informação sobre a existência ou não de relacionamento entre agressor e vítima e o grau desta relação foram encontrados. Em alguns casos, pude localizar estas informações ou confirmar aquelas encontradas nos BOs nas fichas de processos.

As classificações deduzidas dos registros foram codificadas e, em alguns casos, agrupadas para facilitar sua leitura. São elas: "pai", "padrasto", "namorado", "marido", "outro parente", "vizinho", "conhecido", "relação de trabalho", "outros". A classificação "outro parente" engloba tio, avô, irmão, cunhado etc. Já a classificação "conhecido" agrupa aqueles suspeitos que aparecem deste modo nos relatos, mas cujo grau de relação com a vítima não é explicitado. Patrão e colega de trabalho foram reunidos em "relação de trabalho". Finalmente, foram agrupados em "outros" algumas referências que não puderam ser encaixadas nas categorias citadas.

É preciso ressaltar que as informações referentes ao indiciado que constam dos boletins de ocorrência apresentam um grande número de lacunas. Isto se deve, fundamentalmente, a dois motivos: à não identificação do suspeito, que ocorre principalmente em acusações de estupro, e ao fato de ser a vítima, nesta como também em outras modalidades de acusações de crimes sexuais, aquela quem fornece tais informações, as quais, conseqüentemente, são apresentadas não apenas de seu ponto de vista, mas também de maneira fragmentária.

Não obstante esta situação, que resulta em dados com alto índice de ausência de informação, ainda assim estou convencida de que eles devem fornecer pistas interessantes sobre as características dos crimes em estudo.

Ainda com relação a essas informações, é necessário enfatizar que, como as variáveis consideradas não remetem apenas ao agressor, mas também à relação entre ele e a vítima, um mesmo indivíduo pode ser indiciado em mais de um boletim ou em mais de um inquérito, tornando-se, posteriormente, réu em mais de um processo. Logo, se a unidade de análise for 0 boletim, 0 inquérito ou 0 processo, instaurados para cada vítima, haverá uma inflação artificial no número de indiciados ou processados. Para corrigir isso, considerei, em meu trabalho, apenas um boletim ou um inquérito por indiciado e, caso este seguisse no fluxo, apenas um processo (denúncia, sentença) por processado (denunciado, sentenciado). Mais adiante serão apresentados os gráficos para todas as fases do fluxo, considerando os agressores envolvidos.

Finalmente, é importante dizer que a leitura dos dados apresentada neste artigo assumirá um teor mais descritivo devido ao estágio em que se encontra minha pesquisa. A verificação da existência ou não de correlação entre as variáveis em 
estudo e outras tais como a idade da vítima, a idade do agressor, o estado civil destes, o local do fato e outras, certamente produtiva para uma análise mais detalhada, não será possível no momento. Nesse sentido, previno o leitor de que as interpretações sugeridas aqui têm caráter preliminar.

Passo agora à exposição do comportamento do fluxo no que diz respeito ao relacionamento entre agressor e vítima e ao seu grau.

\section{A representação do relacionamento entre agressor e vítima nas várias fases do fluxo}

\section{0 boletim de ocorrência}

A partir do mapeamento dos dados relativos aos quatro crimes em foco, representado no Quadro 1 e no Gráfico 1, observa-se, nos registros de queixas de estupro, que $47 \%$ dos indiciados são conhecidos da vítima, 33\% são desconhecidos e para 20\% deles não foi possível determinar a relação. Para as queixas de tentativa de estupro, $56 \%$ são conhecidos da vítima, $31 \%$ são desconhecidos e para $11 \%$ não foi possível estabelecer a relação. Já em atentado violento ao pudor, são $70 \%$ de queixas contra conhecidos, $14 \%$ contra desconhecidos e 16\% de queixas em que foi impossível estabelecer a relação entre as partes. Finalmente, 93\% das queixas de sedução são contra conheci- dos, $1 \%$ contra desconhecidos e $6 \%$ sem informação, conforme demonstra o Quadro 1.

Quadro 1

Crimes Sexuais: distribuição do indiciado a partir do seu relacionamento com a vítima

\begin{tabular}{|c|c|c|c|}
\hline Sem & informação & Conhecido & $\overline{\text { D esconhecido }}$ \\
\hline Estupro & $20 \%$ & $47 \%$ & $33 \%$ \\
\hline $\begin{array}{l}\text { Tentativa de } \\
\text { estupro }\end{array}$ & $11 \%$ & $56 \%$ & $31 \%$ \\
\hline $\begin{array}{l}\text { A tentado violento } \\
\text { ao pudor }\end{array}$ & $016 \%$ & $70 \%$ & $14 \%$ \\
\hline Sedução & $6 \%$ & $93 \%$ & $1 \%$ \\
\hline
\end{tabular}

Fonte: Dados de BOs referentes aos anos de 1988 a 1992, DDM de Campinas.

Comparando a distribuição dos indiciados por sua relação com a vítima de estupro com esta mesma distribuição nos outros crimes sexuais analisados, observa-se que os indiciados conhecidos predominam nestes tipos de crimes, nos quais a freqüência de desconhecidos é reduzida, exceção feita aos indiciados por crime de tentativa de estupro, cuja freqüência de desconhecidos aproxima-se daquela observada entre os indiciados por crime de estupro.

Os dados apresentados indicam também que há uma maior proporção de queixas de estupros registradas, pela vítima ou por seu representante legal, contra suspeitos conhecidos. De um lado, eles corroboram 0 pressuposto assumido pelos estudos já citados de que 0 estupro cometido

\section{Gráfico 1}

Crimes sexuais: relação entre indiciado e vítima a partir de dados de BO

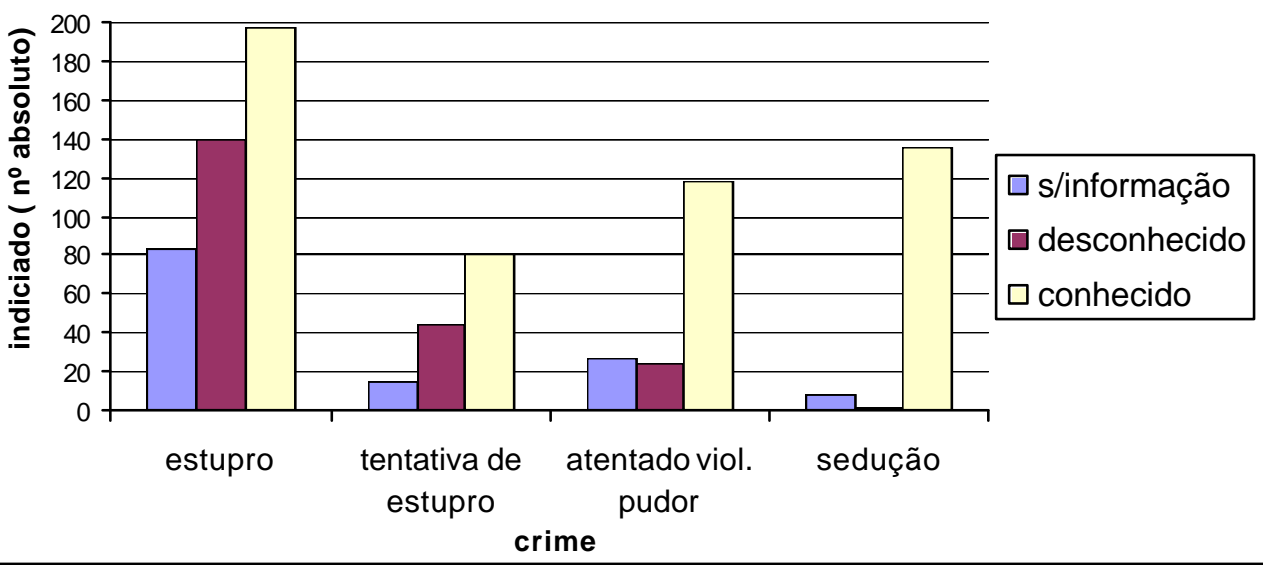


primordialmente por autor desconhecido é um mito que não se sustenta quando confrontado com os registros de queixas desses crimes. Mas, de outro lado, a presença significativa de autores desconhecidos nas queixas de estupro e de tentativa de estupro indica que esses crimes também se caracterizam pela ação de autores desconhecidos e que isto os distingue dos demais crimes sexuais.

Passando agora à descrição do grau da relação existente entre agressor e vítima na fase de registro da queixa, observa-se, conforme mostra o Gráfico 2, que para as queixas de estupro o número de dados sem informação é o mais expressivo (30\%). Isto se deve, como vimos, às lacunas das informações referentes aos indiciados por estupro e à procedência dessas informações, agravadas pela necessidade de detalhamento que esta variável exige. Certamente em decorrência deste último fato, a segunda classificação mais freqüente é "conhecido" (20\%). Os pais, a terceira classificação que mais aparece, representam $14 \%$ dos agressores conhecidos, seguidos de outros parentes (11\%), namorados (8\%), vizinhos $(6 \%)$, padrastos $(4 \%)$, relação de trabalho (3\%), marido (2\%) e outros (2\%).

Mapeando a distribuição do grau de relação entre agressor e vítima nos outros crimes em estudo, é possível observar, para tentativa de estupro, que os pais aparecem com a maior freqüência (20\%). Seguem, em segundo lugar, os registros "sem informação" e "conhecido" (16\%). Os vizinhos e os outros parentes representam a terceira maior freqüência (14\%) e são seguidos do agressor marido $(6 \%)$, do padrasto (4\%), daquele que tem relação de trabalho com a vítima (5\%), do namorado $(3 \%)$ e "outros" (2\%). Para o crime de atentado violento ao pudor, "sem informação" e "pai" representam as duas maiores freqüências, seguidas de perto por "outro parente" (18\%). A terceira maior freqüência é representada pelo padrasto (12\%), vindo em seguida os agressores apenas identificados como conhecidos (10\%), os maridos $(9 \%)$, os vizinhos (7\%), aqueles que tinham, na ocasião dos fatos, relação de trabalho com a vítima (4\%), os enquadrados na classificação "outros" (2\%) e, finalmente, para a categoria "namorado" não foi encontrado registro nenhum. Estes, em contrapartida, representam a grande maioria dos indiciados em crime de sedução (78\%).

Quando detalhamos o grau de relacionamento entre agressor e vítima, verificamos que as queixas de estupro, tentativa de estupro e atentado violento ao pudor assemelham-se quanto à maior freqüência das classificações pai e outros parentes. Essas classificações, somadas, representam 25\% dos suspeitos de crimes de estupro conhecidos, $34 \%$ dos suspeitos de tentativa de estupro e 37\% dos suspeitos de atentado violento ao pudor. Elas configuram o que foi denominado de incesto lato sensu, ou seja, o abuso sexual perpetrado na família por consangǘneos (Cohen, 1993).

Isto nos leva a indagar sobre a semelhança entre os dados aqui apresentados e aqueles levantados pelos autores que estudaram o incesto, citados anteriormente. Mas, para efetuar uma comparação dos dados

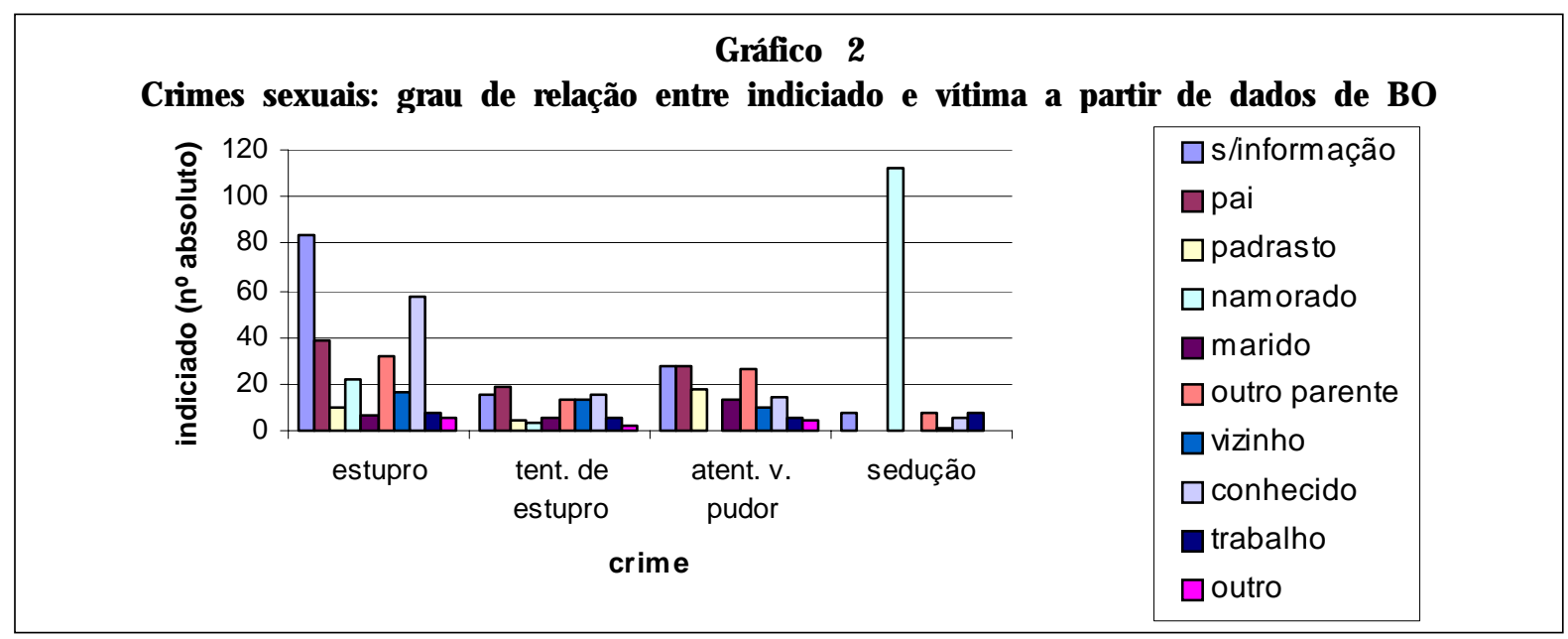


de Cohen e Matsuda (1990, apud Cohen,1993) com aqueles por mim organizados, é preciso considerar (como eles o fazem) somente os crimes que envolvem violência sexual, ou seja, o total das queixas de estupro, tentativa de estupro e atentado violento ao pudor, e conceituar o incesto no sentido amplo, isto é, acrescentando os abusos nas relações padrasto-enteada e madrasta-enteado ao abuso perpetrado por consangüíneos. Deste modo, no total das queixas de crimes sexuais violentos, foram encontrados $25 \%$ de casos de incesto, o que não constitui uma diferença significativa dos $21 \%$ de casos de incesto encontrados por Cohen e Matsuda (1990, apud Cohen,1993).

Partindo das mesmas classificações que definem 0 incesto e tendo por referência o total das queixas de estupro, é possível uma comparação também com os dados apresentados por Saffiotti (1994). Neste sentido, pode-se dizer que os 19\% de estupros incestuosos encontrados na minha pesquisa igualmente não apresentam diferença significativa quando cotejados à proporção de estupros incestuosos (23\%) encontrados pela autora nos registros da 1a D DM de São Paulo, no ano de 1991. Mas essa diferença aumenta se comparamos estes dados aos $25 \%$ de estupros incestuosos encontrados por Saffiotti na 8a D D M em 1992, e torna-se significativa quando os confrontamos com os $36 \%$ de casos similares encontrados na 1a DD M no ano de 1992.

Partindo dos pressupostos de que a elaboração do registro de ocorrência demanda uma compreensão mútua, da queixosa e da atendente policial, sobre 0 que aconteceu, com base no senso comum que ambas possam admitir sobre o evento (Cicourel, 1968), e de que este conhecimento de senso comum tem por referência a forma como esses crimes normalmente são cometidos (Sudnow, 1965), quero sugerir que os vestígios de informação sobre o relacionamento entre agressor e vítima presentes nos registros de ocorrência indicam que os suspeitos reconhecidos como autores de crimes sexuais violentos (estupro, tentativa de estupro, atentado violento ao pudor) são freqüentemente conhecidos da vítima e não poucas vezes têm com esta vínculo familiar, sobretudo paterno. Já suspeitos sem relacionamento algum com a vítima são identificados sobretudo como autores de estupros e também de tentativa de estupro.

Assim, na fase de queixa, antes de os casos registrados serem submetidos ao processo de seleção e de decisão do que deve ou não ser apreciado como "caso de polícia" pela delegada titular e à decisão dos queixosos de acionar ou não o Sistema de Justiça, são apontados como autores de estupros pessoas de diversas formas conhecidas da vítima, embora possam ser destacadas as relações intrafamiliares e, em menor medida, mas ainda significativamente representados, os suspeitos desconhecidos.

0 inquérito policial

$\mathrm{Na}$ fase de instauração de inquérito policial, como mostra o Gráfico 3, as relações entre indiciado e vítima de crime de estupro apresentam-se nas seguintes proporções: entre os conhecidos, $28 \%$ tiveram inquéritos instaurados, contra $69 \%$ que tiveram inquéritos não instaurados, e para 3\% o desfecho é desconhecido. Entre os indiciados desconhecidos, 8\% tiveram inquéritos instaurados, contra $89 \%$ não instaurados, e para $3 \%$ o desfecho é desconhecido. Vale lembrar que a ausência de informação sobre a natureza da relação é bastante expressiva.

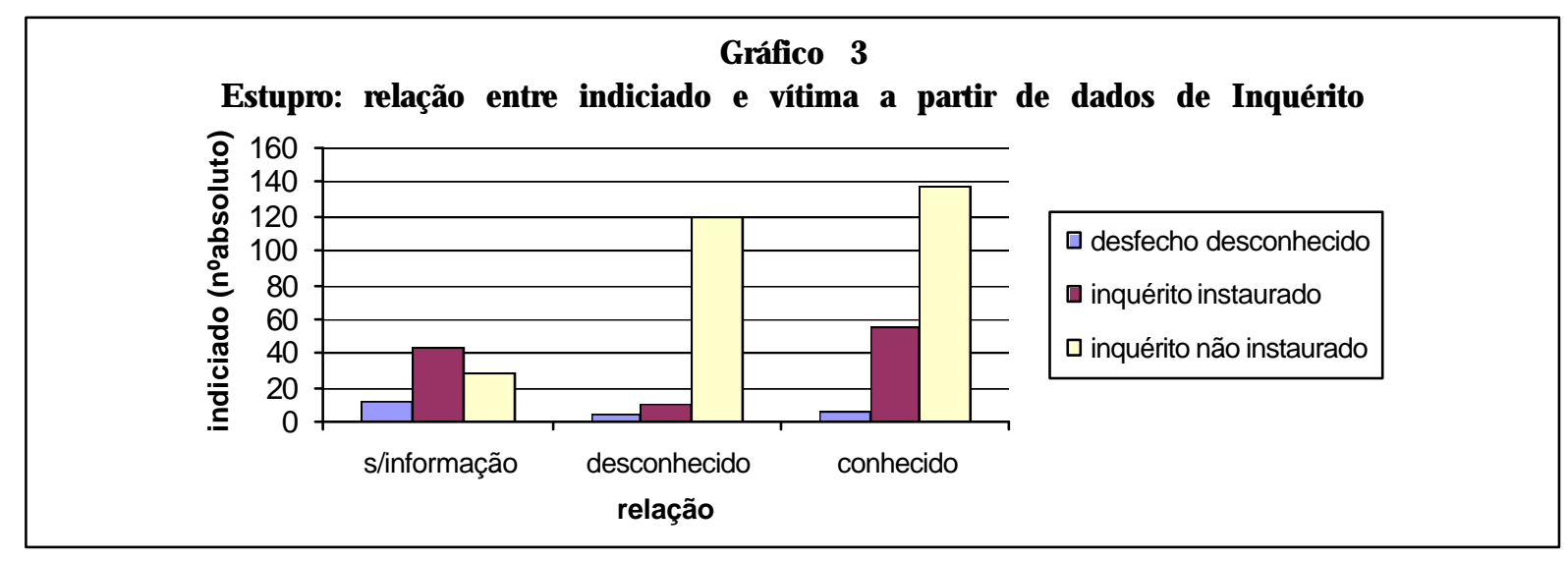


Uma primeira leitura desses dados demonstra que a proporção de inquérito instaurado/inquérito não instaurado contra indiciados desconhecidos é significativamente menor do que aquela observada para os indiciados conhecidos. Para melhor analisar esta situação, é necessário contextualizar esses dados a partir da reconstituição dos próprios procedimentos adotados para a instauração dos inquéritos.

A instauração de um inquérito policial em caso de estupro resulta de um conjunto de decisões tomadas em diferentes instâncias. A primeira delas é a identificação da ocorrência criminal pela autoridade policial, com base, inicialmente, nas informações do BO, no laudo do exame de conjunção carnal e, posteriormente, nos depoimentos dos envolvidos. 0 procedimento seguinte consiste em submeter a vítima ou seu representante à decisão de iniciar a ação penal, pois, do ponto de vista penal, como vimos, tal decisão é considerada de foro pessoal e configura uma ação penal privada, excetuando-se os casos em que a vítima é filha e menor de 14 anos, ou se encontra sob a responsabilidade do réu, e aqueles em que a agressão resulta em morte ou lesão grave, situações em que o Estado é obrigado a dar início a uma ação pública através do Ministério Público, independente da vontade dos queixosos. Nas ocorrências em que não existem indícios suficientes de autoria, ou em que não há elementos para justificar uma denúncia, a queixa acaba sendo arquivada.
Como esses procedimentos são geralmente anotados no alto do formulário de registro, foi possível codificá-los e agrupá-los. Cabe dizer que, por não serem sempre manifestos, ou por se referirem a uma série de situações que a própria polícia considerou indefinidas, encontrei uma alta porcentagem de lacunas. Assim, se considerarmos apenas os dados de solução conhecida (com a ressalva de que os de desfecho desconhecido, aqui, foram distribuídos na mesma proporção para cada categoria, o que não deve ocorrer de fato), é possível observar que, na categoria "inquérito não instaurado", a solução mais encontrada foi a desistência da vítima, ou de seu representante legal, de acionar o Estado para a resolução do conflito (35\%), seguida da solução "suspeito não identificado" (28\%) e, por último, dos casos arquivados por determinação da autoridade policial (6\%). Já na categoria "inquérito instaurado", as ações de natureza privada (22\%) predominam sobre as ações públicas (9\%). É o que mostram os dados do Gráfico 4, organizados a partir das anotações dos BOs sobre procedimentos e soluções dadas às queixas de estupro.

Nas situações que envolvem autores desconhecidos, é comum que estes não venham a ser identificados, uma vez que a prática das policiais da DDM de Campinas (que se enquadra no comportamento das DD Ms em geral, conforme o diagnóstico sobre estas instituições realizado em 1992 pela America's Watch) é, na maioria dos casos, a de não proceder à investigação. Embora a atividade por

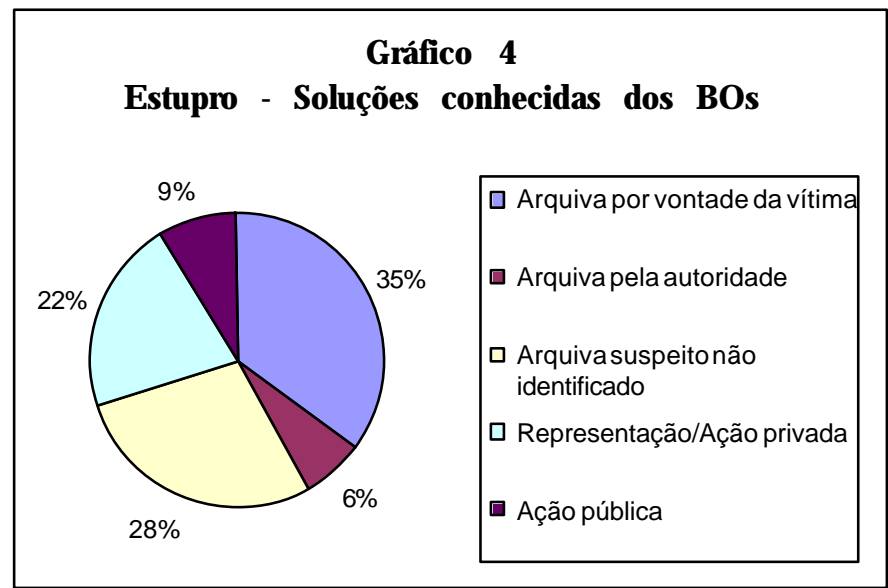


excelência da polícia em geral seja aquela desenvolvida pela linha de frente (Bittner, 1990), nas DD Ms as investigadoras não possuem preparo nem foram treinadas na atividade de investigação. Sem qualificação e mal equipadas para enfrentarem criminosos nas ruas, estas acabam realizando tarefas mais burocráticas, como cumprir ordens de serviços (encaminhar intimações, verificar endereços etc.). ${ }^{21}$ Contudo, naqueles casos considerados muito graves, quando, por exemplo, são identificadas várias ações perpetradas com um mesmo modus operandi ou, em outros termos, nos casos de estupros cometidos em série, recorre-se ao auxílio de outras delegacias, e então procede-se à investigação, geralmente a partir da "lógica do inverso", ou seja, prende-se primeiro o suspeito para depois reconstituir sua culpa (Paixão,1982).

Deste modo, a leitura que coloca os dados em contexto sugere que o reduzido número de suspeitos desconhecidos da vítima na altura do inquérito deve-se, em boa parte, à não identificação destes a partir do trabalho de investigação. Por outro lado, pode-se supor uma forte probabilidade de que certos suspeitos desconhecidos indiciados em inquéritos sejam presos durante as investigações, tendo em vista a hipótese de prisão temporária prevista em lei, cuja finalidade é assegurar 0 sucesso das investigações policiais. ${ }^{22}$
Já a proporção de inquérito instaurado/ inquérito não instaurado para indiciados conhecidos acompanha o mesmo padrão para os quatro crimes em estudo: cerca de $30 \%$ dos inquéritos foram instaurados e mais de $65 \%$ das queixas foram arquivadas (Vargas, 1997). É possível detalhar melhor 0 perfil do indiciado conhecido a partir da descrição da variável "grau de relação entre indiciado e vítima”, mas antes é necessário enfatizar 0 alto índice de dados sem informação - a maior freqüência - cuja causa foi referida anteriomente. A segunda maior freqüência, destacando-se em relação às outras, é a da classificação "pai"; desconsiderando a freqüência "sem informação", ela representa $46 \%$ dos conhecidos. Também é possível observar, a partir do Gráfico 5, que a menor proporção de inquéritos instaurados em relação aos não instaurados encontra-se na classificação "conhecido", seguida das classificações "namorado", "marido" e "outro parente".

Chama a atenção, na classificação "pai", 0 número de inquéritos não instaurados, tendo em vista a obrigatoriedade da ação penal pública para essas situações. Uma primeira possibilidade a ser considerada é a de não retorno e/ ou não localização da vítima e do agressor após a elaboração do BO, tornando irrealizável a instauração de inquérito. Mas também foi possível observar a prática, não

\section{Gráfico 5}

\section{Estupro: grau de relação entre indiciado e vítima a partir de dados de Inquérito}

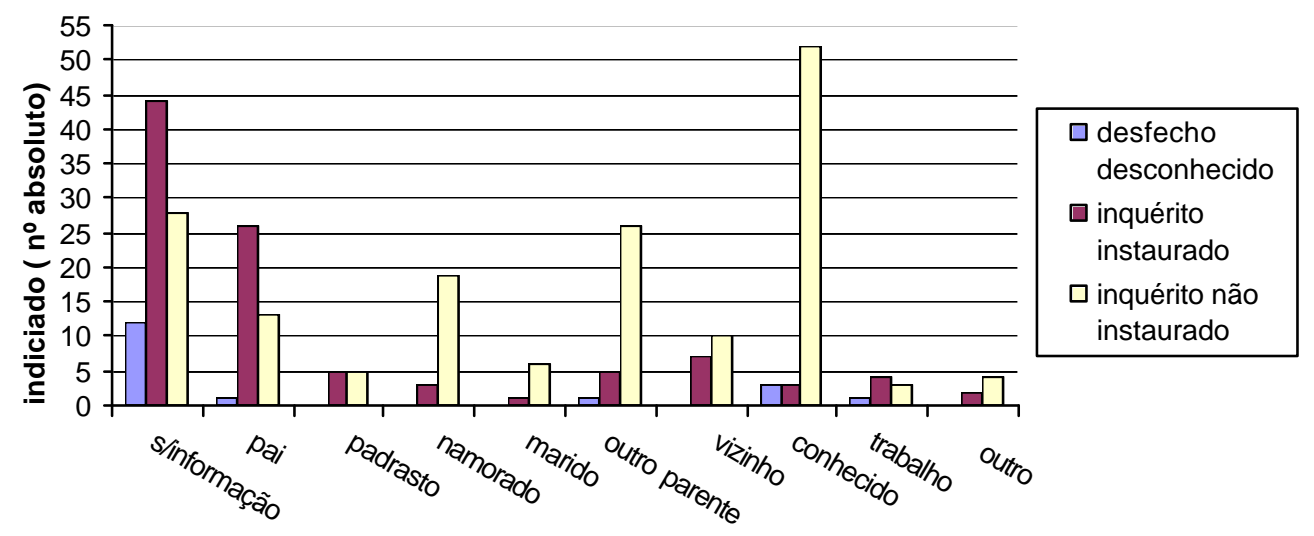


rara, nesses casos, da desqualificação da queixa de estupro após uma primeira apreciação feita pela delegada (o que configura 0 poder discricionário da polícia). Segundo as policiais, são recorrentes as situações em que qualquer aproximação de natureza sexual é considerada pelos autores da queixa como um estupro ${ }^{23}$ ou, ainda, os casos de queixas falsas motivadas por conflitos intrafamiliares, as quais acabam sendo desmentidas logo nos primeiros depoimentos, devido à presença de narrativas contraditórias. Mas há, também, uma outra possibilidade a ser considerada: a de que as vítimas filhas tinham mais de 14 anos por ocasião do fato, 0 que as exclui da ação penal pública, ficando a decisão de acionar a justiça a seu encargo ou a cargo de seu representante legal.

Dados sobre a idade da vítima e seu cruzamento com as variáveis em estudo devem fornecer melhores indicações sobre este aspecto. Como essas informações ainda não puderam ser correlacionados, devido ao estágio em que se encontra minha pesquisa, para interpretar o comportamento dos dados referentes à não instauração de inquérito para o agressor pai, para outros parentes e também para 0 agressor marido, tomarei por base a observação feita em campo e a literatura mais citada a este respeito. Minha experiência no campo sugere que, nos casos envolvendo familiares, sobretudo pais, a desqualificação, quando possível, é feita pela própria vítima ou por sua mãe. Cabe notar, contudo, que em casos envolvendo pais e padrastos, uma vez iniciado o inquérito, mesmo que as queixosas voltem atrás na denúncia, é praxe os autos serem encaminhados ao promotor assim mesmo. Já a literatura aponta que uma denúncia põe em perigo não só o indivíduo, mas também a comunidade à qual pertencem 0 acusador e 0 agressor, tomando difícil a sustentação de uma denúncia envolvendo pessoas próximas, sobretudo da mesma família (Malinowski, 1982; Boltanski, 1990).

Nas denúncias de crimes sexuais, são raros os exames de perícia médica conclusivos, ${ }^{24} 0$ que torna a palavra da vítima um elemento fundamental a ser trabalhado na construção de evidências; conseqüentemente, seu perfil identitário e comportamental acaba sendo reconstituído. Pude observar que esses perfis são elaborados na interação, tendo por referência várias tipificações policiais ativadas para interpretar falas e cenas, tipificações alimentadas por crenças relacionadas às sexualidades infantil, masculina e feminina (Souza et al., 1993) - em se tratando da sexualidade feminina, observei que essas crenças não foram necessariamente suplantadas nas DDMs. Quando a esta característica do crime sexual é acrescentada a da proximidade entre os protagonistas, menor credibilidade é conferida à narrativa da vítima, sendo ponderadas as suas motivações, a existência de conflitos etc. Talvez por esta razão, quando a vítima conhece 0 agressor, por laços de amizade, namoro, casamento ou outros, ela se sinta desmotivada a prosseguir com a queixa.

Busquei argumentar, nesta seção, que a relação existente entre agressor e vítima condiciona, de diferentes maneiras, a instauração ou não do inquérito policial. Como vimos, quando 0 autor é desconhecido, verifica-se um alto índice de desistência da vítima em acionar a justiça, em boa medida devido à não identificação do suspeito pela polícia. Já quando 0 agressor é conhecido, 0 alto índice se explica pelas relações preestabelecidas. A denúncia significa a quebra de tais relações, e quando cabe à vítima ou aos seus familiares decidirem sobre mantê-la, muitas vezes eles optam pela retirada da queixa. ${ }^{25}$ Por outro lado, relações preestabelecidas diminuem a validade da acusação (Boltanski, 1990), e o ceticismo decorrente deste fato acaba por desestimular a vítima de prosseguir com a queixa.

\section{A denúncia}

$\mathrm{Na}$ fase de denúncia, $57 \%$ dos réus são conhecidos da vítima, $12 \%$ são desconhecidos e para 31\% não foi possível estabelecer o grau de relação. Observa-se, a partir do Gráfico 6, um baixo índice de desconhecidos não denunciados, principalmente se comparado aos não denunciados conhecidos. Por outro lado, há uma freqüência significativa de desfechos desconhecidos tanto para os réus conhecidos (39\%) como para os desconhecidos (45,5\%), em razão do tempo de duração dos inquéritos. Ora, essa duração parece ser decisiva para a interpretação do comportamento dos dados. 

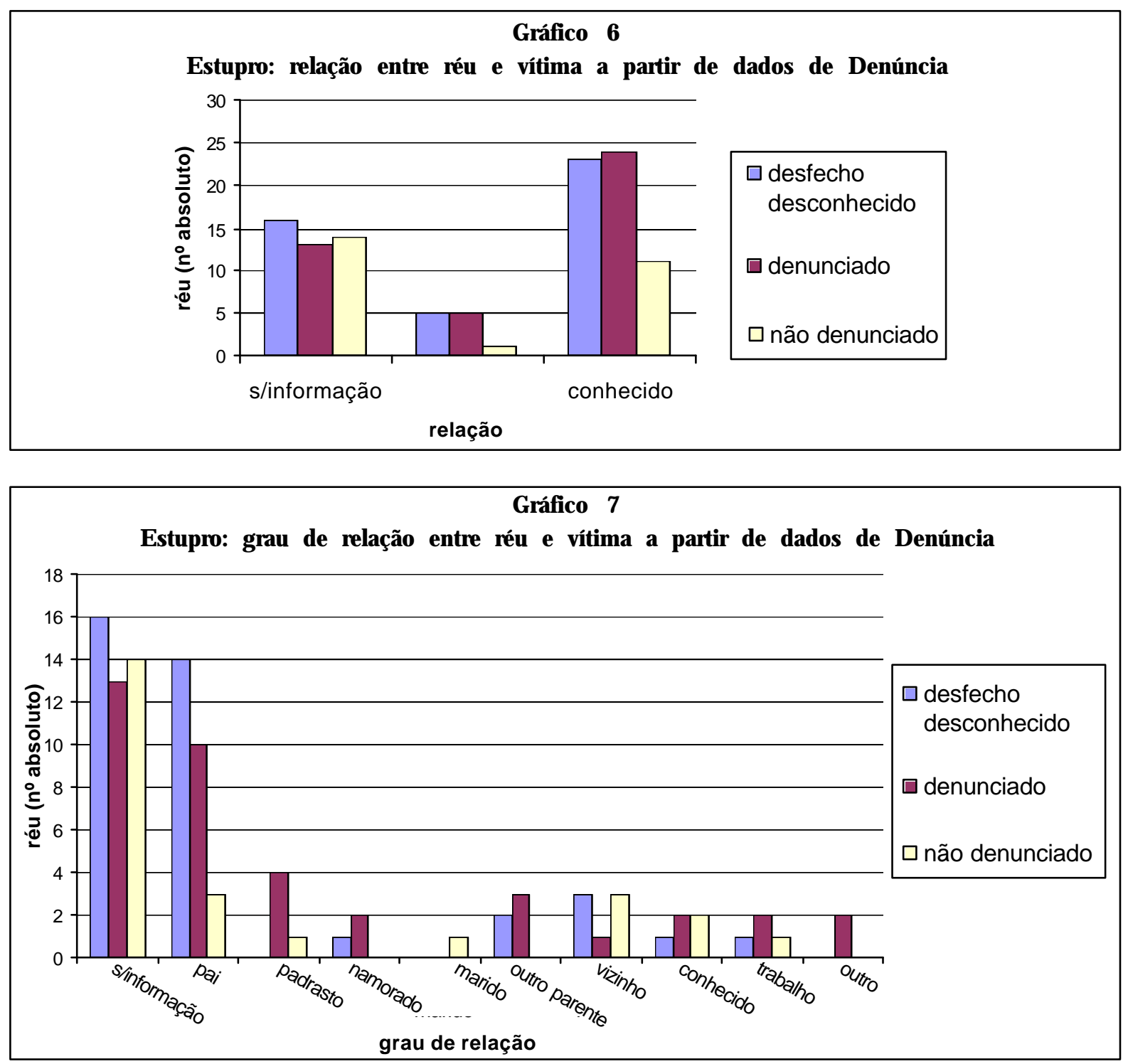

Por determinação do Código do Processo Pe nal (CPP), o inquérito com réu preso em flagrante ou preventivamente deve terminar em dez dias. Já a denúncia, nesta circunstância, deve ser oferecida em cinco dias. Quando o réu encontra-se solto, 0 prazo para a finalização do inquérito é de 30 dias e 0 de apresentação da denúncia, de 15 dias. Caso haja dificuldades para a elucidação do caso, o Código prevê o alargamento do prazo, mediante a remessa dos autos ao Fórum para a obtenção de novo prazo, a ser marcado pelo juiz. Contudo, durante minha pesquisa de campo pude observar a prática cotidiana das policiais e do Ministério Públi- co com relação aos prazos estipulados pelo CPP: em geral, segue-se o prazo para réus presos; com relação aos réus soltos, é comum 0 não cumprimento dos prazos.

Esta regra nos sugere que a agilidade na elaboração dos inquéritos e na instauração dos processos é definida pela gravidade imputada ao crime, muitas vezes justificando uma prisão. Em oposição, a morosidade pode estar associada ao reconhecimento de que se tratam de casos não graves, possuindo, assim, maiores chances de não serem denunciados, ou, então, à decisão dos operadores de não efetuar a prisão. 
Numa tentativa de contextualizar os dados da denúncia, podemos supor, para os casos dos desconhecidos denunciados, que estes foram considerados graves, tendo em vista seu baixo índice de não denúncia, resultando na provável prisão dos réus. Uma proporção maior de réus não denunciados entre os agressores conhecidos sugere um outro desfecho. Uma melhor descrição do desfecho dos casos envolvendo réus conhecidos na altura da denúncia nos é fornecida pela variável "grau de relação entre indiciado e vítima", representada no Gráfico 7.

Observa-se, a partir desta variável, que, descontada a classificação "sem informação", os pais, padrastos e outros parentes são os mais denunciados. Os primeiros representam $38 \%$ dos réus conhecidos da vítima. Já dentre os não denunciados, destacam-se os pais e vizinhos (27\%), bem como os conhecidos (18\%). A proporção dos desfechos desconhecidos para os pais é bastante alta, o que talvez indique que seus processos são demorados e que boa parte deles não foram presos durante 0 processo. ${ }^{26}$

Também chama a atenção 0 número de denúncias não proferidas nas classificações "pai" e "padrasto", devido, provavelmente, à desistência da vítima maior de 14 anos, quando lhe é permitido decidir se quer ou não prosseguir com a acusação.

\section{A sentença}

$\mathrm{Na}$ fase de sentença, $68 \%$ dos condenados são conhecidos da vítima, 21\% deles são desconheci- dos e para $11 \%$ não foi possível estabelecer a relação. Conforme mostra 0 Gráfico 8 , todos os réus desconhecidos da vítima cujo destino é conhecido foram condenados, ao passo que 59\% dos conhecidos obtiveram a condenação.

Por se tratar de um fluxo em movimento, ou, melhor dizendo, de situações iniciadas em tempos diferentes, a fase da sentença está representada por um reduzido número de casos que alcançaram uma decisão. Isto quer dizer que a configuração que os dados assumem hoje deve, provavelmente, se alterar à medida que os processos em andamento vão alcançando uma definição. Por isso, exercitar uma interpretação desta fase requer muito cuidado.

Nota-se que a configuração atual é construída segundo um eixo temporal: são processos que alcançaram a sentença devido à sua antigüidade ou à sua agilidade. O corre que os casos passados, que poderiam fornecer 0 desenho final mais provável do fluxo, fundem-se aos casos mais recentes que, por algumas razões, alcançaram rapidamente a sentença. Uma forma de desfazer essa fusão é investigar essas razões, procurando os significados que elas possam trazer à leitura dos dados no formato em que se apresentam no Gráfico 8.

Como vimos, casos que alcançam rapidamente uma sentença podem referir-se a réus presos durante 0 processo, pois os prazos estabelecidos nos códigos costumam ser seguidos. Por outro lado, já foi observado que réus presos preventivamente, durante o processo, ou já tendo cumprido

Gráfico 8

Estupro: relação entre réu e vítima a partir de dados de Sentença

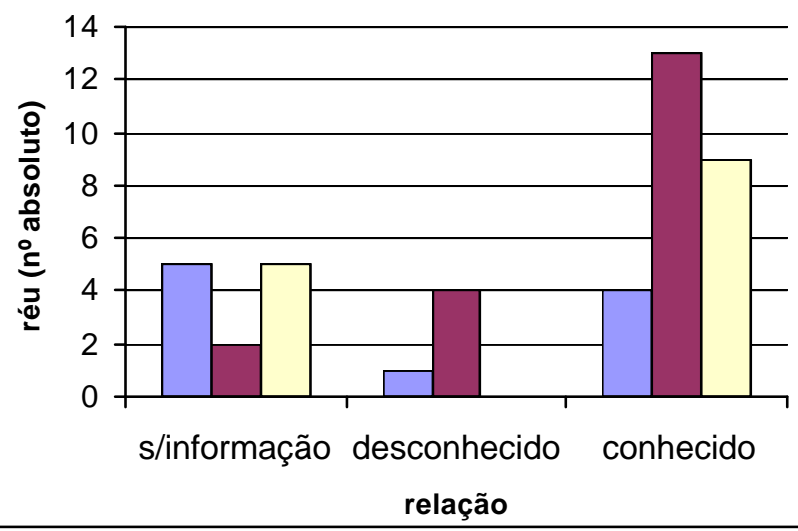

$\square$ desfecho desconhecido

$\square$ condenado

$\square$ absolvido 


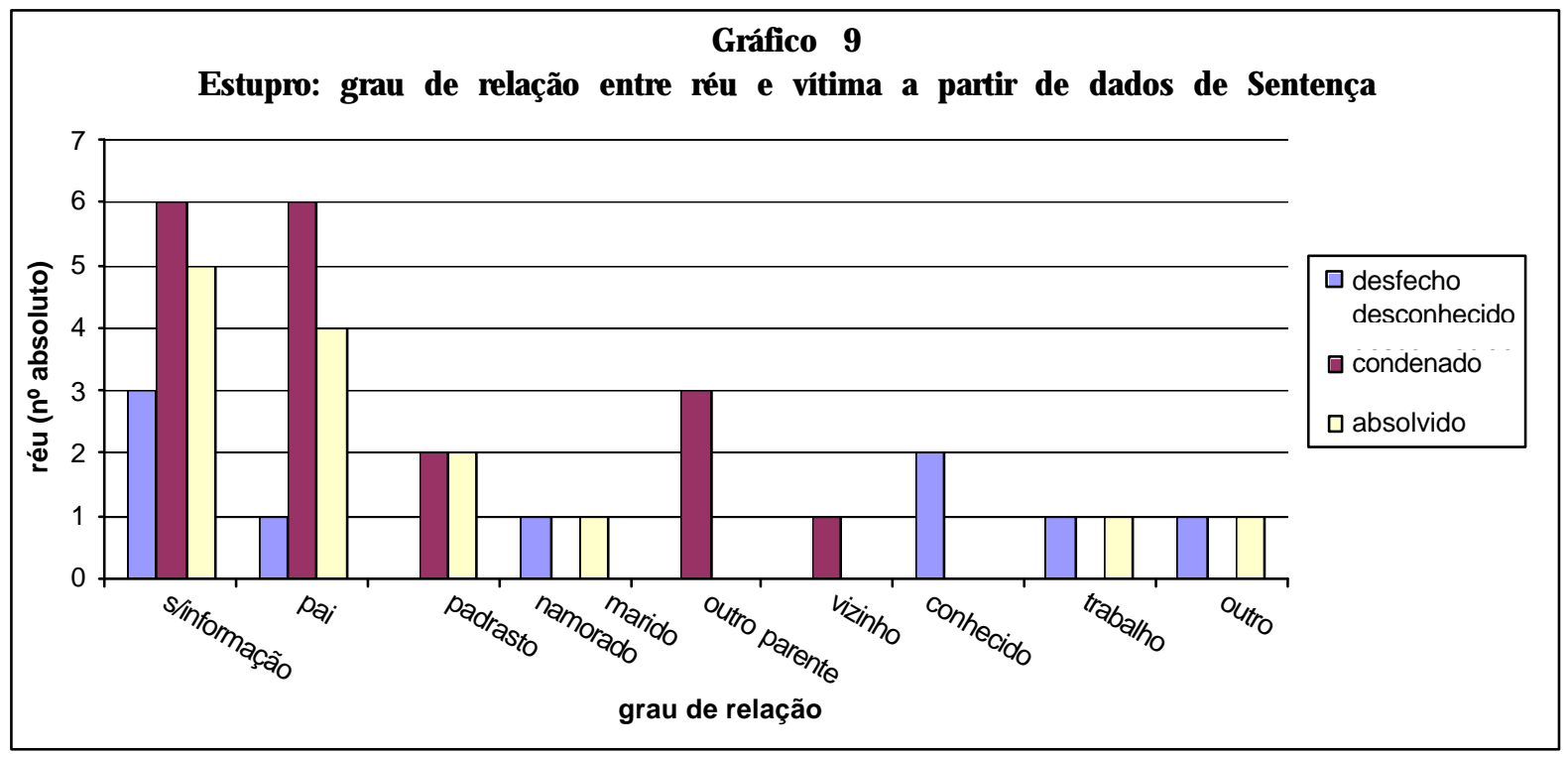

pena tendem mais a obter uma sentença de condenação (Cesdip, 1995). Este é possivelmente o caso dos réus desconhecidos, para os quais se verifica a inexistência de sentença absolutória.

O detalhamento do grau da relação entre os envolvidos pode ajudar a esclarecer melhor como se distribui a sentença para os réus que tinham relacionamento com a vítima. A partir do Gráfico 9, verifica-se que, descontados os casos sem informação, os mais condenados são os pais $(50 \%)$, os outros parentes $(25 \%)$ e os padrastos $(17 \%)$. Por outro lado, os pais e os padrastos são também os mais absolvidos.

Suponho que uma explicação plausível para o comportamento dos dados na fase da sentença deve ser centrada em dois eixos. Um deles referese ao conhecimento, partilhado pelos operadores e certamente utilizado pelos advogados como estratégia para conseguir a absolvição de seus clientes, de que não é rara a ocorrência de trama, motivada por vingança, por interesse etc., em que a vítima é instruída a mentir. Um outro eixo diz respeito ao fato de que, na altura do processo, é comum 0 arrependimento da queixa nos casos em que a vítima é filha ou enteada. Ora, de acordo com 0 modelo acusatório em vigor no Brasil, os elementos colhidos na fase investigatória prévia, realizada pela polícia, servem exclusivamente para formar a convicção do acusador - 0 Ministério Público -, não podendo ser tomados como provas no processo, nem tampouco servir ao convencimento do juiz. Assim, a investigação deve ser novamente realizada na fase de juízo, ocasião em que se volta a repetir as provas produzidas na polícia (G rinover, 1994). No estudo em foco, o desmentido da queixa dada na polícia durante a instrução criminal na justiça impede a construção daquela que é considerada a principal prova nesses crimes: 0 testemunho da vítima. Quando isto ocorre, a sentença é de absolvição.

Portanto, uma interpretação possível para 0 comportamento dos dados referentes ao relacionamento entre agressor e vítima na fase de sentença é a de que autores de crimes considerados graves, provavelmente crimes em série, representam a maioria dos condenados desconhecidos da vítima. Quanto aos autores conhecidos, excluídas as possibilidades de armação e, sobretudo, de obstrução da prova testemunhal em juízo, pais, principalmente, mas também padrastos e outros parentes representam a grande maioria dos condenados.

\section{0 relacionamento entre as partes no fluxo do Sistema de Justiça Criminal}

Nesta seção, tentarei desenvolver, a partir da apresentação dos dados do fluxo do Sistema de Justiça Criminal, o argumento de que a ima- 
gem do estuprador típico quanto à característica relacionamento existente entre agressor e vítima vai sendo construída ao longo do fluxo, a partir da associação das disposições e procedimentos definidos nos códigos com os casos concretos considerados característicos, negociada e manipulada por todos os envolvidos - protagonistas e operadores do sistema.

Conforme mostram os Gráficos 10 e 11, da interação entre queixosos e atendentes, por ocasião da queixa, resulta um modelo de agressor que se caracteriza tanto por seu relacionamento com a vítima como pela falta deste. Queixas de estupros intrafamiliares, mas também contra suspeitos apenas conhecidos ou que mantêm um relacionamento mais íntimo com a vítima constituem o universo dos BOs. Na altura do inquérito, este modelo de relacionamento é filtrado em conseqüência de negocia- ções efetuadas entre os protagonistas e as policiais, provenientes da aplicação de certas regras estatuídas, tais como a natureza da ação penal, a prisão durante o processo, a investigação dos crimes de autoria desconhecida etc. Assim, na fase de inquérito, 0 modelo caracteriza-se pela predominância de agressores conhecidos da vítima, sobretudo de pais, e pela freqüência reduzida de desconhecidos, provavelmente autores de crimes considerados graves. Tal modelo não se altera na fase de denúncia, sofrendo apenas um pequeno rearranjo quanto ao grau de relacionamento entre agressor e vítima, com a diminuição da proporção de pais em favor de outras classificações tais como padrasto, outro parente etc. É possível que, na altura da sentença, 0 modelo de agressor esteja condicionado pela aplicação de certas disposições definidas nos códigos referentes à duração dos processos. Contudo, vimos

\section{Gráfico 10}

Estupro: relação entre réu e vítima a partir do comportamento do fluxo

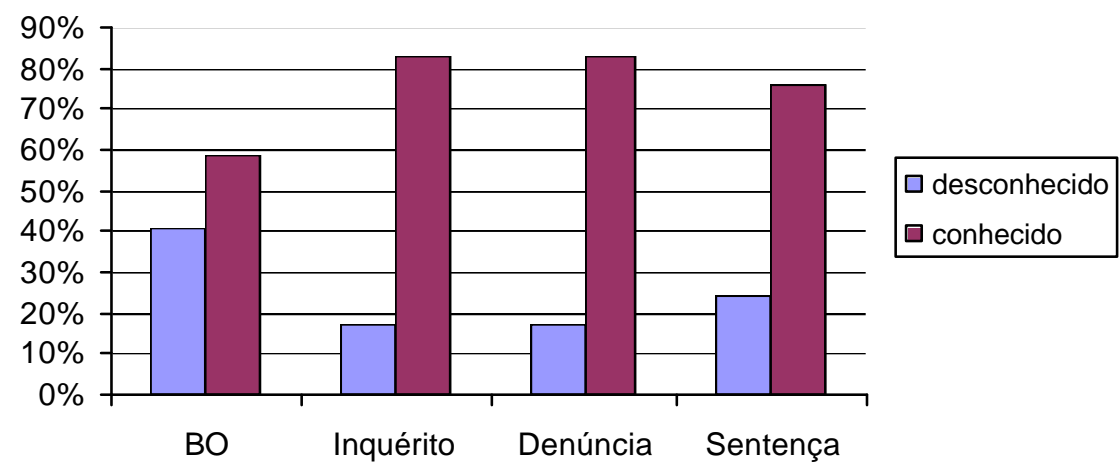

Gráfico 11

Estupro: grau de relação entre réu e vítima a partir do comportamento do fluxo
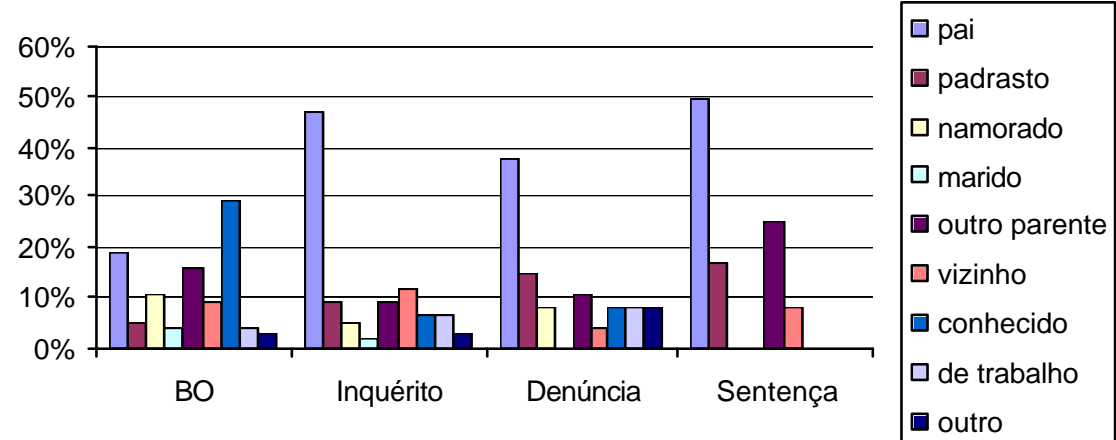
que elas permitem apontar, com respeito ao relacionamento entre agressor e vítima, o perfil daqueles que costumam ser condenados como estupradores. Este é basicamente 0 mesmo que se desenha no fluxo a partir do inquérito: desconhecidos envolvidos em casos graves, possivelmente seriais, e conhecidos intrafamiliares, pais, sobretudo, mas também outros parentes e padrastos.

Enfim, ao longo do funcionamento do fluxo, a classificação da relação entre agressor e vítima e de seu grau apresenta uma mesma configuração que se desenha a partir da fase do inquérito, quando conhecidos, principalmente pais, padrastos e outros parentes, mas também certos desconhecidos, prováveis acusados de casos graves, tornam-se os suspeitos e, posteriormente, os autores privilegiados do crime de estupro. Com referência à relação de conhecimento entre agressor e vítima, pode-se dizer que, ao longo do fluxo, ela vai sendo associada às caracterizações típicas usadas pelos agentes policiais e judiciais para definirem 0 crime de estupro.

\section{Conclusão}

Ao longo deste artigo procurei argumentar que 0 relacionamento entre agressor e vítima é uma caracterização importante do crime de estupro, considerada nos códigos e utilizada pelos operadores do Sistema de Justiça Criminal e pelas queixosas para conferir significado a este crime.

Interessada em investigar em que medida 0 fato de o suspeito ser ou não conhecido da vítima condiciona as decisões no Sistema de Justiça Criminal, reconstituí quantitativamente 0 fluxo que este sistema produz tendo por referência 0 relacionamento entre as partes, bem como o seu grau. Desse modo, foi possível demonstrar que, a partir da fase de inquérito, os suspeitos conhecidos, principalmente familiares - e, destes, sobretudo os pais - , são os mais culpabilizados pelo sistema. Também indiquei que os autores desconhecidos parecem só ser penalizados quando cometem estupros considerados graves, geralmente em série.

A descrição do comportamento, ao longo do fluxo, das variáveis em estudo torna visível a predisposição, por parte do sistema, em punir o incesto, pelo menos no que se refere àquele cometido contra vítimas menores de 14 anos. Procurei sugerir que a absolvição, nestes casos, é decorrente sobretudo da atitude das vítimas de desmentir a queixa, com o intuito de inocentar autores pais e padrastos ou, em menor medida, de culpabilizá-los falsamente, motivadas ou instruídas por conflitos na família. É nesse sentido que as decisões sobre casos envolvendo familiares são consideradas difíceis, principalmente se comparadas àquelas que envolvem desconhecidos.

Quanto ao grau de integração e/ ou disjunção do sistema com respeito a esta variável, considero que a uniformidade apresentada pela configuração do fluxo a partir da fase de inquérito indica que as decisões tomadas pelos operadores dos diferentes subsistemas tendo por referente 0 relacionamento entre as partes encontram-se bastante articuladas entre si.

Para terminar, quero afirmar que o Sistema de Justiça Criminal foi aqui entendido como locus de implementação de controle social, exercido em vários níveis e pelos diferentes atores do sistema - queixosa, policial, testemunha, promotor, juiz etc. - , tendo por referência suas concepções acerca de quebra de regra, transgressão, anormalidade e sobre como elas devem ser solucionadas. A disjunção entre as soluções oferecidas pelo sistema e aquelas solicitadas pelas queixosas incita-nos a uma reflexão sobre a adequação do Sistema de Justiça Criminal para atender às demandas de resolução de conflitos feitas por aqueles que a ele recorrem.

\section{NOTAS}

1 O estudo sobre o Sistema de Justiça Criminal realizado por Coelho (1986) e o diagnóstico Indicadores sociais de criminalidade elaborado pela Fundação João Pinheiro (1987) chamam a atenção para a necessidade de se privilegiar o fluxo de processamento de pessoas e papéis entre os diversos subsistemas que compõem 0 Sistema de Justiça Criminal, deslocando, assim, a investigação dos processos de decisão de cada um desses subsistemas para a análise do fluxo.

2 Dentre esses estudos vale destacar: Correa (1983), Fausto (1984), Feiguin et al. (1987), Ardaillon e Debert (1987), 
Azevedo e Azevedo Guerra (1988) e, mais recentemente, Cohen (1993), Saffiotti (1994), Passetti (1995), Soares (1996), Vargas (1997) e Pimentel et al. (1998).

3 O trabalho de Azevedo e Azevedo Guerra (1988) sobre vitimização sexual de crianças e adolescentes foi realizado a partir de levantamento efetuado no Município de São Paulo, em documentos consultados na polícia, nas varas de menores, na Fundação Estadual do Bem-Estar do Menor (FEBEM) e no Instituto Médico Legal (IML). Já o estudo de Cohen e Matsuda (1990, apud Cohen,1993) foi desenvolvido a partir de questionários dirigidos às vítimas de violência sexual que compareceram ao IML de São Paulo durante seis meses do ano de 1992.

4 Estatísticas são produtos organizacionais; logo, a geração de medidas diferentes reflete procedimentos distintos de registro de informações (Fundação João Pinheiro, 1987).

5 Cohen (1993) define o incesto como um abuso intrafamiliar, com ou sem violência explícita, caracterizado pela estimulação sexual intencional por parte de algum membro do grupo que possui um vínculo parental com o (a) abusado (a) pelo qual lhe é proibido o matrimônio.

6 Trata-se de um trabalho mais abrangente sobre a violência contra crianças e adolescentes no Brasil, no qual a autora dedica um capítulo ao estudo da violência sexual, apresentando os resultados da pesquisa por ela realizada em duas DD Ms de São Paulo em 1993.

7 Estes dados fazem parte de um estudo no qual as autoras buscaram analisar processos judiciais e acórdãos de estupro no Brasil a partir de uma perspectiva de gênero.

8 A violência em crimes de estupro deve ser provada. Em certas circunstâncias enumeradas em lei (art. 224 do $\mathrm{CP}$ ), tais como (a) a menoridade da vítima (menos de 14 anos); (b) ser alienada ou débil mental e isto ser do conhecimento do agente; e (c) não poder por qualquer outra causa oferecer resistência, o legislador presume que tenha havido violência. No caso da menoridade da vítima, ainda que ocorra o consentimento desta, este não é considerado válido.

9 Em um instigante artigo denominado "Normal crimes", Sudnow (1965) defende a tese de que a regra que descreve a atribuição de status penal a um acontecimento deve ser procurada nos crimes normais, ou seja, no conhecimento típico adquirido pelos operadores da justiça sobre a forma como esses crimes são regularmente cometidos.

10 Entrevista com delegada.

11 Entrevista com promotor de justiça.

12 Decorrente dos diversos movimentos sociais surgidos na década de 80, em particular do movimento feminista, a criação de delegacias de atendimento a mulheres foi uma tentativa de superar uma das críticas mais contundentes feitas às delegacias de costumes: o descaso e o preconceito com que as vítimas eram atendidas e, conseqüentemente, o baixo índice de denúncias verificado.
13 Ao receber 0 inquérito, 0 Ministério Público pode devolvê-lo à autoridade policial, solicitando novas diligências necessárias ao oferecimento da denúncia.

140 juiz dirige o processo no sentido de que, dentre outras coisas, a ele cabe a condução do interrogatório do réu e dos depoimentos das testemunhas e a interpretação das respostas a serem registradas nos autos (Kant de Lima, 1997).

$15 \mathrm{Na}$ literatura acadêmica nacional, uma perspectiva instigante para o estudo do Sistema de Justiça Criminal é aquela que sugere ser este formado de subsistemas frouxamente integrados, possuindo algum grau de coesão, mas também de disjunção (Coelho, 1986).

16 Campinas é o segundo aglomerado urbano do Estado de São Paulo, com uma população girando em torno de 1 milhão de habitantes. Como a maioria das cidades do interior paulista, Campinas viveu nos últimos anos profundas mudanças em sua estrutura produtiva, acompanhando o ritmo de crescimento econômico da capital do estado. Aparentemente, essas indicações credenciam-na como locus de ocorrência de criminalidade, tendo em vista a tendência, a partir dos anos 80 , de aumento da criminalidade violenta nas grandes cidades brasileiras.

17 Indivíduos e instituições, em geral, sabem o risco que correm ao se exporem à observação (Besson, 1995). Ora, a polícia lida com esta questão de maneira particular, visto que observar é justamente a parte principal de seu ofício. Por este motivo, o acesso aos dados registrados pelas policiais só foi possível mais de seis meses depois de iniciado o trabalho de campo, quando uma certa relação de confiança já estava estabelecida.

18 Os quadros com as tabulações dos dados e seus cruzamentos não serão apresentados aqui, devido à falta de espaço, mas encontram-se à disposição dos interessados.

19 Algumas informações ausentes dos BOs puderam ser identificadas no Livro de Registro de Ocorrências. Antigamente, as queixas eram registradas pela polícia em um livro denominado Livro de Queixas. Com o aumento das denúncias e 0 aperfeiçoamento do caráter burocrático desta organização, a queixa passou a ser registrada em um formulário específico, o BO. Entretanto, o uso do Livro de Queixas, desde então denominado Livro de Registro de Ocorrências, permaneceu como um indicador de referência dos registros. Deste modo, foi possível, durante o levantamento das informações, comparar a lista dos BOs reproduzidos com a lista que consta no Livro.

20 A ausência destas classificações deve-se ao fato de que o BO se destina à anotação de toda e qualquer ocorrência criminal, desde acidentes de trânsito até homicídios.

21 "Aqui, a função do investigador é localizar as partes que não comparecem, fazer os relatórios, e é só. Porque aqui, pela escassez de pessoal, não há uma equipe de investigação que pega um boletim de ocorrência de autoria desconhecida e vai investigar. 0 serviço de investigação nosso aqui é zero!". Entrevista com investigadora. 
22 A Lei dos Crimes Hediondos (Lei 8072/ 90) criou a hipótese de prisão temporária de 30 dias, prorrogável por mais 30, a ser aplicada em caso de extrema e comprovada necessidade, para permitir a coleta de provas quando são poucos os dados de convicção obtidos, ou quando o suspeito não tem residência fixa, ou não forneceu elementos para o esclarecer sua identidade, podendo eventualmente vir a fugir.

23 "A maioria acha que qualquer coisa de conotação sexual é estupro. Eu já tive vítima que sexo oral para ela é estupro." Entrevista com escrivã.

24 Seja em razão do tempo decorrido entre 0 ato e 0 exame, seja devido à atitude da vítima de tomar banho logo após o estupro, seja pela dificuldade de detectar vestígios inerentes ao ato (alguns casos de atentado violento ao pudor, ou de estupro de mulher não virgem), ou outros motivos.

25 Isto não lhes garante a manutenção destes laços; ao contrário, é comum o desmembramento da família em decorrência da queixa.

26 Foi possível observar em campo que a prisão do agressor pai é considerada uma decisão difícil, pois leva-se em conta o seu papel de provedor da família.

\section{BIBLIOGRAFIA}

AMERICA'S WATCH. (1992), Injustiça criminal X a violência contra a mulher. Rio de Janeiro, Human Rights Watch.

ARDAILLO N, D. e DEBERT, G.G. (1987), Q uando a vítima é mulher. Brasilia, Conselho Nacional dos Direitos da Mulher (CNDM)/ CEDAC.

AZEVED O, M.A.eAZEVED O G UERRA,V.N.(1988), Pele de asno não é só história: um estudo sobre a vitimização sexual de crianças e adolescentes em família. São Paulo, Rocco.

BECKER, H. (1963), O utsiders. Studies in the sociology of devianœ. Nova York, The Free Press of Glencoe.

BESSO N, J.L. (org.). (1995), A ilusão das estatísticas. São Paulo, Ed. da Unesp.

BITTNER, E. (1990), A spects of police work. Boston, Northeastern University Press.

BOLTANSKI, L. (1990), "La dénonciation publique", in L. Boltanski, L'amour et la justice comme compétences, Paris, Éditions Métailié.

CESDIP - Centre de Recherches Sociologiques sur le D roit et les Institutions Pénales. (1995), Arrestations, classements déferements, jugements. Suivi d'une cohorte d'affaires pénales de la police à la justice. Organizado por B. Aubusson de Cavarlay e M.S. Huré. Paris, CESDIP, mimeo.
CICOUREL, A.V. (1968), The social organization of juvenile justice. Nova York, John Wiley \& Sons, Inc.

- (1974), "Police practices and officials records", in R. Turner (ed.), E thnomethodology, Ontário, Penguin Books.

CÓDIGO DO PROCESSO PENALANOTAD O.(1986). Org. Damásio E. de Jesus. São Paulo, Saraiva.

CÓDIGO PENALE SUA INTERPRETAÇÃOJURISPRUDENCIAL. (1987). São Paulo, Editora Revista dos Tribunais.

COELHO, E.C. (1986), "A administração da justiça criminal no Rio de Janeiro: 1942-1967". D ados - Revista de Ciências Sociais, Rio de Janeiro, Iuperj, 29, 1: 61-81.

. (1988), "A criminalidade urbana violenta". Dados - Revista de Ciências Sociais, Rio de Janeiro, Iuperj, 31, 2: 145-83.

. (1993), “Censo penitenciário do Rio de Janeiro 1988". Textos de Pesquisa, Rio de Janeiro, Núcleo de Pesquisa ISER.

COHEN, C. (1993), "O incesto", in M.A. Azevedo e V.N. Azevedo Guerra (orgs.), Infância e violência doméstica: fronteiras do conhecimento, São Paulo, Cortez.

CORREA, M. (1983), Morte em família. Rio de Janeiro, $\mathrm{G}$ raal.

ELLICKSON, R.C. (1994), O rder without law: how neighbors settle disputes. Cambridge, Harvard University Press.

ESPÍRITO SANTO, L. (1991), Caso de polícia: o senso comum da ordem. Belo Horizonte, PUC-MG, mimeo.

FAUSTO, B. (1984), Crime e cotidiano - a criminalidade em São Paulo (1880-1924). São Paulo, Brasiliense.

FUNDAÇÃO JOÃO PINHEIRO. (1987), Indicadores sociais de criminalidade. Belo Horizonte, Fundação João Pinheiro.

FUNDAÇÃO SEADE. (1987), U m retrato da violência contra a mulher - 2.038 boletins de ocorrências. Org. D. Feiguin, E. Bordini, M.A. Medrado e M.E. Paternostro. São Paulo, Fundação SEADE.

GOFFMAN, E. (1982), E stigma: notas sobre a manipulação da identidade deteriorada. Rio de Janeiro, Zahar. 
GRINOVER, A.P. (1994), "A instrução processual em Ibero-América". Revista Brasileira de Ciências Criminais, ano 2, 6, abr.-jun.

HAG AN, J., HEWIT, J.D . e ALVIN, D .F. (1979), “Cerimonial justice: crime and punishment in a loosely coupled system". Social Forœes, 58, 2: 506-27.

KANT DE LIMA, R. (1994), A polícia da cidade do Rio de Janeiro: seus dilemas e paradox os. Rio de Janeiro, Polícia Militar do Rio de Janeiro. . (1997), "Polícia e exclusão na cultura judiciária". Tempo Social, São Paulo, Depto de Sociologia da USP, 9(1): 169-83.

MALINOWSKI, B. (1982), Crimen y costumbre en la sociedad salvaje. Barcelona, Ariel.

PAIXÃO , A.L. (1982), “A organização policial numa área metropolitana”. Dados - Revista de Ciências Sociais, Rio de Janeiro, Iuperj, 25, 1.

PAIXÃO , A.L. eBEATO FILHO , C.C. (1995), Mediação e dissuasão de conflitos sociais. Trabalho elaborado para o XIX Encontro da LASA, Washington.

PASSETTI, E. (org.). (1995), V iolentados: crianças, adolescentes e justiça. São Paulo, Imaginário.

PIMENTEL, S., SCHRITZMEYER, A.L. ePANDJIARJIAN, V. (1998), E stupro: crime ou "cortesia"? A bordagem jurídica de gênero. Porto Alegre, Sérgio Antônio Fabris Editor.

SAFFIOTI, H.I.B. (1994), A vida por um fio: a violência contra crianças e adolescentes no Brasil contemporâneo. Trabalho apresentado no XVIII Encontro Anual da Anpocs, Caxambu, MG.

SAPORI, L.F. (1996), A defesa pública e a defesa constituída na justiça criminal brasileira. Trabalho apresentado ao GT Direitos, Identidades e Ordem Pública, XX Encontro Anual da Anpocs, Caxambu, MG.

SMITH, D.E. (1978), "K is mentally ill. The anatomy of a factual account". Sociology. The Journal of The British Sociological A ssociation, 12(1): 2353.

SOARES, B.M. (1996), "Delegacia de atendimento à mulher: questão de gênero, número e grau", in L.E. Soares (org.), V iolência e política no Rio de Janeiro, Rio de Janeiro, Relume Dumará, pp. 107-125.
SO UZA, E., MATEUS, F. e LO PE S, P. (1993), "D ecisões em matéria penal: 0 caso da violação e 0 peso das variáveis extra legais". Sociologia - Problemas e Práticas, 14: 141-57.

SUDNOW, D. (1965), "Normal crimes: sociological features of the Penal Code". Social Problems, 12, Winter: 255-64 e 269-70.

VARGAS, J.D. (1996), “O fluxo do sistema judiciário para crimes sexuais. Campinas - um estudo de caso". A nais do Enoontro $\mathrm{N}$ acional de Produtores e U suários de Informações Sociais, E conômicas e Territoriais - A Sociedade, Rio de Janeiro, IBGE, tomo 3, vol. 8. . (1997), 0 fluxo do Sistema de Justiça C riminal para crimes sex uais: a fase policial. Campinas, dissertação de mestrado, Departamento de Antropologia da Universidade Estadual de Campinas.

ZALUAR, A.M. (1985), A máquina e a revolta. São Paulo, Brasiliense.

. (1993), A autoridade, o chefe e o bandido: dilemas e saídas educacionais. Trabalho apresentado no seminário internacional Autoritarismo Social e Educação, São Paulo, Centro de Estudos Avançados da USP, mimeo.

- (1996), O utilitarismo sociológico e as políticas públicas. Trabalho apresentado no GT Cidadania, Conflito e Transformações Urbanas, XX Encontro Anual da Anpocs, Caxambu, MG . 